\title{
PENGARUH BUDAYA ORGANISASI, GAYA KEPEMIMPINAN DAN PENGAMBILAN KEPUTUSAN TERHADAP KOMITMEN ORGANISASI Studi Kausal pada PT SUCOFINDO (Persero)
}

\author{
Yayan Sudaryana *) \\ email : yayansudaryana@yahoo.com
}

\begin{abstract}
ABSTRAK
PENGARUH BUDAYA ORGANISASI, GAYA KEPEMIMPINAN DAN PENGAMBILAN KEPUTUSAN TERHADAP KOMITMEN ORGANISASI, STUDI KAUSAL PADA PT. SUCOFINDO (Persero). Penelitian ini bertujuan untuk mengetahui pengaruh budaya organisasi, gaya kepemimpinan, dan pengambilan keputusan terhadap komitmen organisasi pada PT. Sucofindo (Persero). Survei dilakukan dengan sampel yang dipilih secara acak dari 100 karyawan. Dengan semua variabel dimasukkan ke dalam matriks korelasi, data kemudian dianalisis dengan teknik jalur. Hasilnya menunjukkan bahwa. (1) budaya organisasi memiliki efek langsung pada pengambilan keputusan: (2) budaya organisasi memiliki efek langsung pada komitmen organisasi; (3) gaya kepemimpinan memiliki efek langsung pada pengambilan keputusan, (4) gaya kepemimpinan memiliki efek langsung pada komitmen organisasi; (5) pengambilan keputusan memiliki efek langsung pada komitmen organisasi; (6) budaya organisasi memiliki efek tidak langsung pada komitmen organisasi melalui pengambilan keputusan; dan (7) gaya kepemimpinan memiliki pengaruh tidak langsung terhadap komitmen organisasi melalui pengambilan keputusan. Hasilnya menunjukkan bahwa budaya organisasi, gaya kepemimpinan, dan pengambilan keputusan adalah penentu penting komitmen organisasi.
\end{abstract}

Kata Kunci : Budaya Organisasi, Gaya Kepemimpinan, Pengambilan Keputusan, Komitmen Organisasi

\section{ABSTRACT}

THE EFFECT OF ORGANIZATIONAL CULTURE, LEADERSHIP STYLE, AND DECISION MAKING ON THE ORGANIZATIONAL COMMITMENT A Causal Study on PT. SUCOFINDO (Persero) The study aims to find out the effect of organizational culture, leadership style, and decision making on the organizational commitment on PT Sucofindo (Persero). A survey was conducted with a randomly selected sample of 100 employees. With all the variables put into a correlation matrix, the data was then analysed with the path technique. The result showed that. (1) organizational culture had a direct effect on decision making: (2) organizational culture had a direct effect on the organizational commitment; (3) leadership style had a direct effect on the decision making, (4) leadership style had a direct effect on the organizational commitment; (5) decision making had a direct effect on the organizational commitment; (6) organizational culture had an indirect effect on the organizational commitment through decision making; and (7) leadership style had an indirect effect on the organizational commitment through decision making. The results suggest that organizational culture, leadership style, and decision making are important determinants of organization's commitment.

Keywords: Organizational Culture, Leadership Style, Decision Making, Organizational Commitment *) Dosen Program Studi Magister Manajemen - UNPAM 


\section{PENDAHULUAN}

\section{A. Latar Belakang}

Globalisasi yang terjadi saat ini memberikan dampak yang signifikan bagi kelangsungan hidup organisasi. Globalisasi telah menyebabkan terjadinya perubahanperubahan yang begitu cepat di dalam bisnis, yang menuntut organisasi untuk lebih mampu beradaptasi, mempunyai ketahanan, mampu melakukan perubahan arah dengan cepat, dan memusatkan perhatiannya kepada pelanggan. Globalisasi ini juga dapat memunculkan bahaya, sekaligus kesempatan bagi organisasi.

PT Superintending Company Indonesia (Sucofindo) merupakan perusahaan Badan Usaha Milik Negara (BUMN) berdiri sejak 22 Oktober 1956, dengan alamat kantor di Pancoran, Jakarta Selatan. Saat ini perusahaan ini telah tumbuh dan berkembang hingga wilayah operasionalnya mencakup hampir seluruh nusantara.

PT Superintending Company Indonesia (Sucofindo), memiliki kantor cabang di 27 propinsi, dengan core bussiness meliputi: (a) jasa survey; (b) inspeksi dan (c) supervisi di bidang perdagangan dan perindustrian. Karyawan perusahaan ini tidak kurang dari 3.000 orang yang terdiri atas 700 orang karyawan pusat 2.300 orang tersebar di daerah-daerah, dengan perincian sebagaimana pada tabel 1.1. berikut :

\section{Tabel 1.1}

Karyawan/ti PT. Sucofindo, tahun 2016

\begin{tabular}{|l|c|c|}
\hline \multicolumn{1}{|c|}{ Uraian } & Karyawan Pusat & Karyawan Daerah \\
\hline Laki-laki & 600 orang & 2.264 orang \\
\hline Perempuan & 100 orang & 36 orang \\
\hline Jumlah & 700 orang & 2.300 orang \\
\hline
\end{tabular}

Sumber: PT. SUCOFINDO (Diolah Penulis).

Visi dan Misi PT Superintending Company Indonesia (Sucofindo) adalah sebagai berikut :

Visi:

Menjadi perusahaan kelas dunia di bidang inspeksi, supervisi, pengkajian, dan pengujian yang berorientasi pada kepuasan pelanggan.

Misi:

Untuk menjadi perusahaan yang memberikan kualitas pelayanan yang profesional, menguasai teknologi, dan berstandar internasional.

Kendala dan Tantangan yang dihadapi PT. Sucofindo saat ini antara lain adalah :

1. Ketatnya persaingan, termasuk dengan perusahaan asing.

2. Banyaknya perusahaan yang memberikan jasa sejenis.

3. Pesatnya perkembangan teknologi.

Dalam menghadapi kendala dan tantangan untuk mencapai tujuan organisasi, tentunya diperlukan dukungan dari karyawan PT. Sucofindo yang memiliki komitmen tinggi yang akan membawa sukses bagi organisasi. Meskipun demikian, pada kenyataannya dalam 
mencapai tujuan organisasi, masih ditemui adanya permasalahan terkait dengan: absensi kehadiran karyawan/ti, yang tercatat dalam satu tahun mencapai lebih kurang lebih $2 \%$. Jika hal ini dibiarkan, maka tidak tertutup kemungkinan akan dapat menghambat pencapaian tujuan organisasi. Di samping masalah absensi ini, masalah lain yang dihadapi oleh perusahaan ini adalah adanya sejumlah karyawan yang keluar masuk (turnover) dari perusahaan ini.

Karyawan yang bekerja dengan tanggung jawab penuh, dapat dikatakan bahwa mereka memiliki komitmen yang tinggi untuk keberhasilan organisasi. Komitmen organisasi dapat dipengaruhi oleh berbagai faktor, seperti: (a) budaya organisasi; (b) gaya kepemimpinan; (c) pengambilan keputusan; (d) kepuasan kerja, dan banyak lagi faktor yang dapat mempengaruhi komitmen organisasi tersebut.

\section{B. PERUMUSAN MASALAH}

Mengacu pada latar belakang diatas, maka maka masalah yang akan dikaji dan dianalisis dalam penelitian ini dapat dirumuskan sebagai berikut:

1. Apakah terdapat pengaruh langsung budaya organisasi terhadap pengambilan keputusan?

2. Apakah terdapat pengaruh langsung budaya organisasi terhadap komitmen organisasi?

3. Apakah terdapat pengaruh langsung gaya kepemimpinan terhadap pengambilan keputusan?

4. Apakah terdapat pengaruh langsung gaya kepemimpinan terhadap komitmen organisasi?

5. Apakah terdapat pengaruh langsung pengambilan keputusan terhadap komitmen organisasi?

6. Apakah terdapat pengaruh tidak langsung budaya organisasi terhadap komitmen organisasi melalui pengambilan keputusan?

7. Apakah terdapat pengaruh tidak langsung gaya kepemimpinan terhadap komitmen organisasi melalui pengambilan keputusan?

\section{KAJIAN TEORITIK, KERANGKA BERPIKIR DAN HIPOTESIS}

\section{A. ACUAN MODEL}

Penelitian ini mengacu pada model yang dikembangkan oleh Colquitt, Lepine, Wesson (2009: 8) yang dapat dilihat sebagai berikut. 
JURNAL ILMIAH ILMU MANAJEMEN

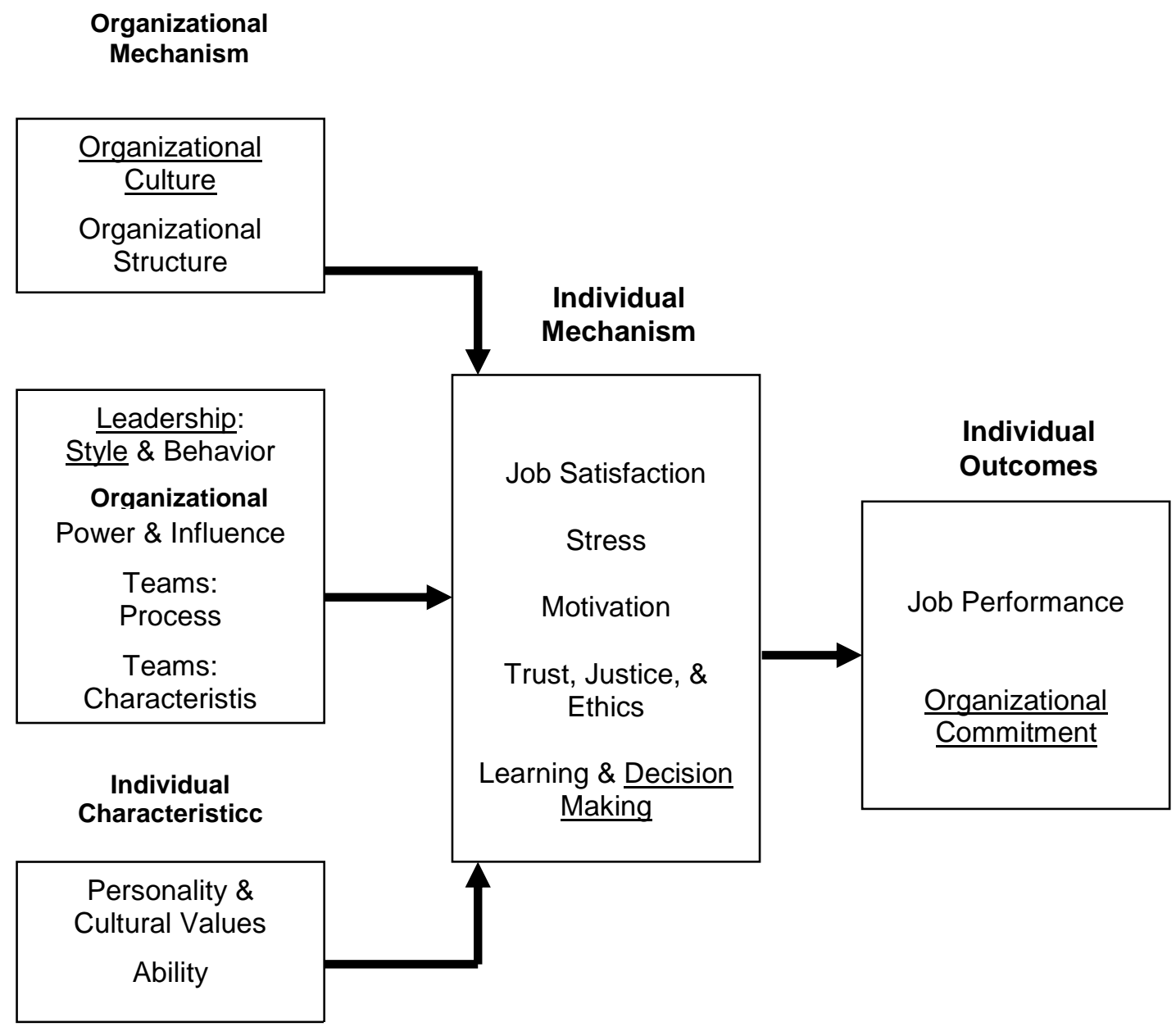

Gambar 2.1. :Model Integratif Perilaku Organisasi

Berdasarkan acuan model di atas, maka dısusunıan modeı penelıtıan sebagaı berıkut.

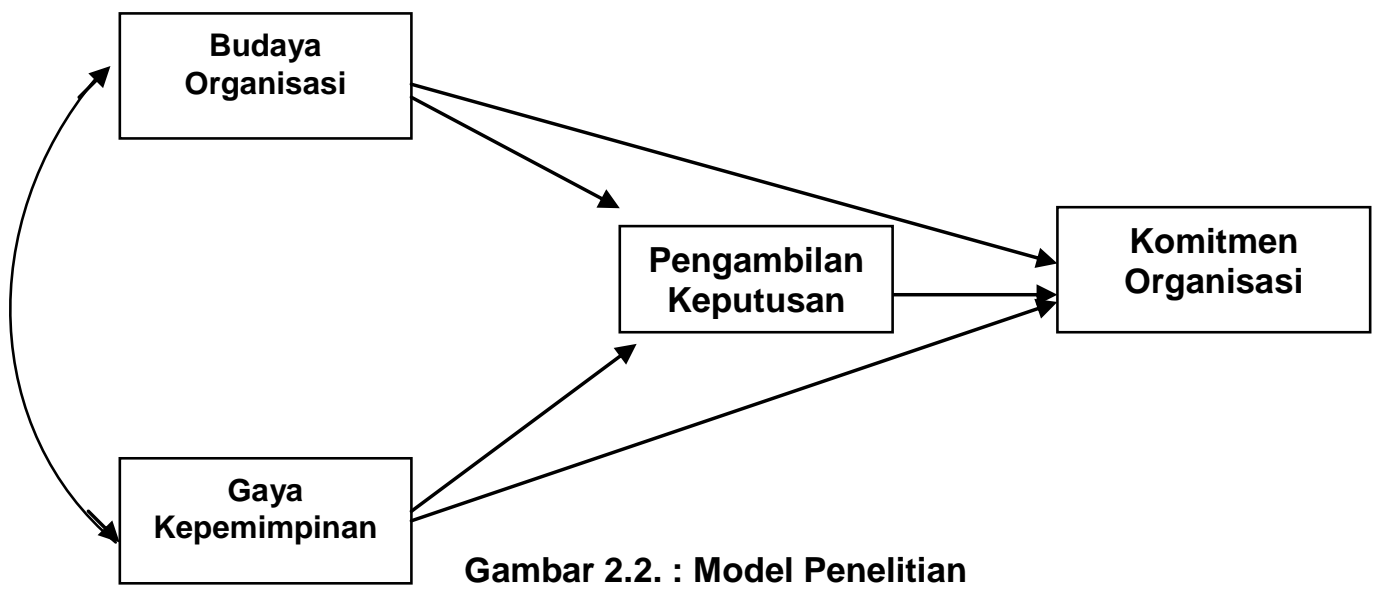


Untuk memahami terminologi yang digunakan pada model di atas, berikut akan dibahas kerangka teoretik masing-masing variabel.

\section{B. DESKRIPSI TEORITIK}

\section{Budaya Organisasi}

Budaya organisasi dapat dipahami dari berbagai sudut pandang dan dimensi. Salah satu di antaranya adalah menurut pandangan Robins (2001: 201) yang menegaskan bahwa budaya organisasi adalah persepsi umum yang dianut oleh anggota organisasi atau suatu sistem dari pengertian bersama yang dimiliki oleh para anggotanya. Mengutip pendapat Schein, Luthans (2001: 497) mendefinisikannya sebagai sebuah bentuk asumsi dasar yang dibangun atau dikembangkan oleh sekelompok orang, dan dianggap cukup sehingga diajarkan kepada para anggota baru sebagai cara yang benar dalam mempersepsikan, berpikir, dan merasakan hubungan dengan masalah-masalah yang dihadapi organisasi. Pada sisi lain, Kreitner dan Kinicki (2004: 706) mendefinisikan budaya organisasi sebagai perekat sosial yang mengikat para anggota organisasi secara bersamasama melalui nilai-nilai, simbul-simbul, dan cita-cita yang dianut bersama. Relevan dengan pendapat sebelumnya, George dan Jones (2002: 494) mendefinisikan budaya organisasi sebagai seperangkat nilai-nilai dan norma-norma informal yang mengendalikan cara orangorang atau kelompok dalam suatu organisasi melakukan interaksi satu sama lainnya di dalam dan di luar organisasi. Melengkapi pendapat di atas, Hofstede (1994: 140) mendefinisikan budaya organisasi sebagai pikiran yang diprogramkan secara kolektif yang membedakan anggota sebuah organisasi dengan organisasi lainnya.

Jika dianalisis lebih lanjut, Kotter dan Heskett (1997: 4) menegaskan bahwa kriteria pertama dapat dikategorikan sebagai budaya tingkat pertama. Aspek ini biasanya sudah terinternalisasi secara lebih dalam pada setiap anggota organisasi. Hal ini membuat budaya tingkat pertama ini tidak tampak secara kasat mata, tetapi dapat dirasakan karena terkait dengan nilai-nilai, norma-norma, asumsi, keyakinan dan sistem yang sudah dibangun oleh suatu kelompok. Hal inilah yang menurut Kotler dan Hesket Ini disebut sebagai "nilai-nilai yang dianut bersama oleh orang dalam kelompok dan cenderung bertahan sepanjang waktu bahkan meskipun anggotanya sudah berubah". Nilai-nilai ini kemudian diwariskan oleh anggota organisasi kepada anggota lainnya yang lebih muda secara turun temurun. Hal ini membuat budaya organisasi pada tingkat pertama tersebut tidak mudah diubah karena diyakini "ada" dan "baik" serta diwariskan secara turun temurun pada anggota organisasi. Masih menurut pendapat di atas, budaya organisasi tingkat kedua merupakan pola atau gaya perilaku suatu organisasi sehingga anggota-anggota baru secara otomatis terdorong untuk mengikuti sejawatnya." Hal ini relatif lebih mudah dapat terlihat karena terkait dengan unsur-unsur "luar", misalnya dari seragam organisasi, simbul-simbul yang digunakan anggota organisasi.

Relevan dengan pendapat sebelumnya, Kotter dan Hesket (1997: 17) menegaskan budaya organisasi yang kuat tercermin dari kekonsistenan para manajer atau anggota 
organisasi lainnya memegang teguh nilai-nilai dan metode kerja yang mereka bangun. Dalam konteks ini, tidak mustahil seorang bawahan dapat menegur atasannya jika pihak atasan keluar dari nilai-nilai atau metode, maupun cara kerja yang biasa mereka lakukan. Selanjutnya dijelaskan bahwa budaya organisasi yang kuat perlu dijaga dan dikembangkan karena dapat meningkatkan prestasi kerja anggota organisasi maupun kinerja organisasi itu sendiri. Hal ini cukup beralasan sebab kondisi tersebut akan berfungsi (1) menyatukan tujuan anggota organisasi; (2) meningkatkan motivasi kerja para anggotanya, dan (3) memberikan struktur dan kontrol yang ketat pada anggotanya tanpa harus bersandar pada aturan birokratis.

Untuk mengembangkan dan membangun budaya organisasi yang kuat dapat dilakukan melalui perubahan tujuh aspek dasar yang dikembangkan oleh Deal.(1991: 160). Ketujuh aspek tersebut disajikan pada Tabel 2.1 berikut.

Tabel 2.1 Transisi Menuju Budaya organisasi yang Kuat

\begin{tabular}{|l|l|}
\hline \multicolumn{1}{|c|}{ Dari } & \multicolumn{1}{c|}{ Ke } \\
\hline Kompetisi & Kerjasama Kelompok \\
\hline Individualisme & Bekerjasama \\
\hline Diskriminasi & Kesetaraan \\
\hline Bekerja & Bermain \\
\hline Karier & Keluarga \\
\hline Kelayakan & Etis \\
\hline Keuntungan & Karakter Pembeda \\
\hline
\end{tabular}

Sumber: Deal $(1991 ; 160)$

Wagner III dan Hollenbeck (1992: 696) menyimpulkan bahwa ada delapan elemen dalam budaya organisasi yaitu: (1) Ceremonies - upacara atau kegiatan tertentu yang dilakukan oleh anggota organisasi yang menjadi simbol dari organisasi tersebut; (2) Rites atau kegiatan-kegiatan atau upacara sebagai alat mengkomunikasikan ide-ide; (3) Stories atau kejadian-kejadian lama yang membekas secara mendalam dan menjadi norma dan nilai; (4) Myths, yakni hal-hal atau cerita-cerita yang dipercayai; (5) Heroes, yakni kesuksesan seseorang yang merupakan pengejawantahan dari nilai; (6) Superstars, yakni keistimewaan seseorang yang merupakan personifikasi keberhasilan yang dicapai organisasi; (7) Symbols, yakni peristiwa penting yang memungkinkan anggota organisasi tukar menukar ide (lambang-lambang); (8) Language, yakni bahasa yang biasa digunakan.

Elemen-elemen ini terintegrasi secara utuh dan menjadi kepribadian organisasi. Kumpulan elemen-elemen tersebut dapat dijadikan sebagai karakteristik yang membedakan kepribadian satu organisasi dengan organisasi lain. Kepribadian organisasi inilah yang menjadi elemen paling esensial dalam konteks budaya organisasi dan menjadi acuan bagi setiap anggotanya untuk berperilaku di dalam maupun di luar organisasi. 
Berdasarkan uraian tersebut di atas, maka dapat disintesiskan bahwa budaya organisasi merupakan kebiasaan-kebiasaan yang sudah terpola dalam memelihara nilai dan norma yang dianut organisasi meliputi: (1) memberikan kepercayaan terhadap bawahan; (2) menerapkan komunikasi yang terbuka; (3) memperhatikan dan mendukung bawahan; (4) memecahkan masalah dengan tim; (5) menerapkan otonomi dalam pekerjaan; (6) menyediakan akses informasi; dan (7) menetapkan keluaran dan tujuan yang tinggi.

\section{Gaya Kepemimpinan}

Kepemimpinan merupakan "the process of influencing the activities of an individual or a group in efforts toward goal achievement in a given situation".(Hersey dan Blanchard, 2001: 64). Definisi ini mengisyaratkan bahwa kepemimpinan memiliki kriteria (1) sebuah proses mempengaruhi individu atau kelompok; (2) pengaruh tersebut dilakukan untuk mencapai tujuan; (3) proses mempengaruhi ini tergantung pada situasi. Dengan demikian, pengaruh yang dilakukan tidak setiap saat dilakukan sama untuk setiap situasi, namun tergantung pada situasinya.

Relevan dengan pendapat di atas, kepemimpinan juga dapat diartikan sebagai proses mempengaruhi antara seorang pimpinan dan anggotanya untuk mencapai tujuan kelompok, organisasi, dan masyarakat (Avery dan Baker, 1990: 433). Pendapat lain mengatakan kepemimpinan merupakan proses individu-individu mempengaruhi, dengan tindakan mereka, memfasilitasi pergerakan sekelompok orang ke arah pencapaian tujuan yang telah disepakati (Robbins, 1997: 418). Sedangkan, Griffin (2001: 504 - 505) memandang kepemimpinan ini dari dua sudut pandang yang berbeda, yaitu (1) dari sudut proses, yang berarti penggunaan pengaruh yang tidak memiliki kekuasaan memberikan sanksi untuk membentuk tujuan kelompok-kelompok atau organisasi, mengarahkan perilaku mereka untuk mencapai tujuan, dan membantu menciptakan budaya kelompok atau organisasi; dan (2) dari sudut kepemilikan, yang diartikan sebagai seperangkat ciriciri yang menjadi atribut seseorang yang dipersepsikan sebagai seorang pemimpin.

Bender (1997: 7 - 11), melihat kepemimpinan tidak hanya dari dimensi proses mempengaruhi dan mencapai tujuan, tetapi juga dari dimensi figur atau sifat kepemimpinan yang diperlukan pada masa yang akan datang. Ditegaskan bahwa pada masa yang akan datang pemimpin yang diperlukan adalah yang mampu mengantisipasi perubahan, dengan ciri-ciri: (a) kepemimpinan itu menyangkut manusia (Leadership is about people); (b) kepemimpinan merupakan upaya menjadikan diri sendiri menjadi pemimpin yang berarti (Leadership is about being the leader of you ); (c) kepemimpinan itu menyangkut motivasi dari dalam diri (Leadership is about internal motivation); (d) kepemimpinan merupakan perjuangan untuk kesempurnaan, dan menyadari ketidak-sempurnaan diri sendiri (Leadership is about striving for perfection, while accepting our imperfection); (e) kepemimpinan terkait dengan perubahan (Leadership is about change); (f) kepemimpinan menyangkut kepercayaan diri (Leadership is about having confidence); $(\mathrm{g})$ kepemimpinan terkait dengan pertumbuhan (Leadeship is about growth); (h) kepemimpinan terkait 
kepemilikan daya (Leadership is about having energy); (i) kepemimpinan terkait dengan penciptaan suatu pengalaman yang positif (Leadership is about creating a positive experience); (j) kepemimpinan menyangkut menciptakan hasil-hasil (Leadership is about creating results); dan ( $\mathrm{k}$ ) kepemimpinan terkait dengan pengurangan rasa takut dan meningkatkan harapan (Leadership is about reducing fear and increasing hope).

Pendekatan pertama didasarkan atas pandangan bahwa kepemimpinan merupakan seperangkat sifat atau bakat yang dimiliki individu yang membuat mereka mampu untuk memimpin. Sifat-sifat yang dimiliki seorang pemimpin, menurut Wexley dan Yukl (2001: 89), adalah (1) dapat beradaptasi terhadap segala situasi, (2) peduli dengan lingkungan sosial, (3) ambisius dan berorentasi pada prestasi, (4) asertif, (5) kooperatif, (6) mampu membuat keputusan, (7) memiliki ketergantungan, (8) dominan (memiliki hasrat mempengaruhi orang lain), (8) energik, (9) penyabar, (10) percaya diri, (11) toleran terhadap tekanan, dan (12) mau bertanggungjawab. Dari aspek keterampilannya, seorang pemimpin memiliki karakteristik (1) cerdas, (2) keterampilan konseptual, (3) kreatif, (4) diplomatis dan taktis, (5) fasih berbicara, (6) memiliki pengetahuan tentang tugas kelompoknya, (7) memiliki kemampuan administratif, (8) persuasif, dan (9) memiliki keterampilan sosial.

Relevan dengan pendapat di atas, Newstrom dan Davis (2001: 201) menyatakan ciriciri seorang pemimpin, dipandang dari sifatnya, adalah memiliki (1) hasrat personal yang tinggi, (2) hasrat untuk memimpin, (3) integritas personal, dan (4) rasa percaya diri. Dari sudut pandang keterampilannya, seorang pemimpin memiliki (1) kemampuan kognitif, (2) pengetahuan bisnis, (3) karisma, kreativitas, fleksibilitas, dan kepribadian yang hangat.

Kepemimpinan berperspektif perilaku, menurut George dan Jones (2002: 395), pada dasarnya mempelajari kepemimpinan berdasarkan keterampilan yang dimiliki oleh seorang pemimpin. Keterampilan ini secara garis besarnya dapat dibagi ke dalam tiga kategori utama, yakni keterampilan (1) teknik, (2) manusiawi, dan (3) konseptual. Keterampilan teknik terkait dengan pengetahuan dan kemampuan melakukan pekerjaan yang bersifat teknis; Kete-rampilan manusiawi merupakan kemampuan bekerja secara efektif dengan orang-orang, membangun tim kerja dan ini merupakan bagian dari kepemimpinan berperspektif perilaku; keterampilan konseptual adalah kemampuan berpikir dalam bentuk model-model, kerangka kerja, dan hubungan yang luas lainnya.

Pendekatan ketiga - pendekatan situasional - menurut Mullins (2005: 303) dibangun di atas asumsi bahwa tidak ada satu cara pun yang dapat mengarahkan manusia untuk bekerja pada semua situasi, Dengan demikian seorang pemimpin harus memiliki perilaku yang fleksibel, mampu mendiagnosis gaya kepemimpinan yang sesuai dengan situasi yang dihadapinya, serta mampu menerapkannya dengan baik. Relevan dengan pendapat di atas, mengutip pendapat Vroom, Hersey dan Blanchard (2001: 106) mengatakan, "I do not see any form of leadership as optimal all situations. The contribution of a leader's action to the effectiveness of his organization cannot be determined without considering the nature of the situation in which that behavior is displayed" 
Menurut Mullins (2005: 304), untuk mendiagnosis dan menerapkan gaya kepemimpinan yang sesuai dengan situasi yang dihadapi, seorang pemimpin harus memperhatikan tiga faktor utama, yakni: (1) Perhatian terhadap bawahan, yang berarti kepedulian pimpinan terhadap keahlian, pengalaman, kemampuan, pengetahuan tentang tugasnya, tingkat hierarkis, dan karakteristik psikologis; (2) Perhatian terhadap Atasan, yang mencerminkan derajat pelaksanaan pengaruhnya, ataupun kesamaan sikap dan perilakunya pada orang-orang yang di atasnya; (3) Perhatian terhadap Tugas, mencerminkan derajat urgensi waktu yang dimiliki, bahaya fisik, rata-rata kesalahan yang diizinkan, derajat otonomi, luas skop pekerjaan, dan derajat kekaburan pelaksanaan tugas.

Seperti yang telah dijelaskan di atas, salah satu variabel yang menentukan keberhasilan suatu gaya kepemimpinan adalah gaya para pengikutnya. Hal ini relevan dengan pendapat Hersey dan Blanchard yang mengatakan :

"Followers in any situation are vital, not only because individually they accept or reject the leader, but because as a group they actually determine whatever personal power that leader have. If the follower decides not to follow, it really doesn't matter what the other elements in the situation are".

Pernyataan tersebut secara implisit menegaskan bahwa gaya kepemimpinan yang efektif bukan terletak pada kekuasaan pemimpinnya, melainkan kesesuaian antara kematangan pengikutnya dengan gaya yang diterapkan oleh pemimpin. Sebagai contoh: bagi pengikut yang memiliki kematangan rendah, maka gaya kepemimpinan yang efektif adalah gaya otoriter, sedangkan bagi pengikut yang telah memiliki kematangan tinggi, gaya ini dinilai kurang efektif sehingga perlu dilakukan dengan gaya pendelegasian.

Dengan demikian, tidak ada satu gaya pun yang sesuai untuk semua peran dan untuk semua orang sehingga perlu menerapkan gaya yang berbeda untuk menghadapi peran dan orang-orang yang berbeda. Efektivitas penerapan gaya ini terlihat dari sejauh mana gaya yang dimunculkan sejalan dengan perilaku dan kematangan para pengikutnya.

Berdasarkan rangkaian teori di atas, maka gaya kepemimpinan yang dimaksudkan dalam hal ini dapat disintesiskan sebagai sikap dan perilaku dalam mempengaruhi pengikutnya yang terlihat dari: (1) mendelegasikan pekerjaan kepada bawahan yang memiliki kemauan dan kemampuan; (2) membantu jika bawahan kurang mampu, tetapi memiliki kemauan; (3) memberikan tantangan terhadap bawahan yang memiliki kemampuan, tetapi tidak mempunyai kemauan; dan (4) memerintah jika bawahan tidak memiliki kemampuan dan kemauan.

\section{Pengambilan Keputusan}

Menurut Colquitt, Lepine \& Wesson (2009: 119), pengambilan keputusan adalah proses pemecahan masalah melalui identifikasi alternatif pemecahan masalah dan menetapkan alternatif yang paling sesuai. Pendapat lain menegaskan efektivitas pengambilan keputusan sebagai proses menetapkan tujuan melalui dengan keguatan inventarisasi alternatif pemecahan masalah dan menentukan alternatif yang diperhitungkan paling memadai (Hunsaker, 2001: 11). Melengkapi pendapat sebelumnya, Turban, 
Aronson, dan Liang (2005: 11) menyatakan bahwa efektivitas pengambilan keputusan adalah suatu kegiatan memilih di antara beberapa alternatif tindakan untuk tujuan pencapaian satu atau beberapa sasaran.

Jika pendapat di atas diintegrasikan, maka pengambilan keputusan adalah sebuah proses pemecahan masalah atau pencapaian tujuan yang dilakukan melalui identifikasi beberapa alternatif pemecahan masalah, membandingkan alternatif tersebut satu sama lain dan menetapkan alternatif yang "dianggap" paling memuaskan. Istilah "dianggap" paling memuaskan secara implisit menegaskan bahwa belum tentu alternatif yang dipilih merupakan yang terbaik, tetapi baru sebatas anggapan bahwa alternatif ini dapat memuaskan pihak yang mengambil keputusan.

Robbins dan Judge (2001: 123) menyatakan individu sering berpikir bahwa pembuat keputusan terbaik adalah yang rasional dalam arti konsisten dan memaksimalkan nilai pilihan dalam batas-batas tertentu. Lebih lanjut dinyatakan bahwa model pengambilan keputusan rasional dapat dilakukan dengan mengikuti enam langkah. Langkah-langkah tersebut adalah: (1) merumuskan permasalahan (define the problem), (2) mengidentifikasi kriteria keputusan (identify the decision criteria), (3) mengalokasikan bobot pada kriteria tersebut (allocate weights to the criteria), (4) mengembangkan alternatif-alternatif (develop the alternatives), (5) mengevaluasi alternatif-alternatif tersebut (evaluate the alternatives), dan (6) memilih alternatif yang terbaik (select the best altemative). Menurut kedua pakar di atas, pengambilan keputusan terjadi sebagai reaksi terhadap suatu permasalahan yang timbul karena adanya suatu penyimpangan antara kondisi saat ini dengan kondisi yang dikehendaki, yang memerlukan pemikiran mengenai tindakan alternatif.

Jika dikaitkan dengan konteks penelitian ini, maka pengambilan keputusan yang akan dikaji adalah pengambilan keputusan yang efektif, bukan yang efisien. Artinya, sejauh mana keputusan tersebut dapat mencapai tujuan yang dikehendaki. Di samping pencapaian tujuan tersebut, keputusan yang efektif adalah keputusan yang dapat mengoptimalkan beberapa faktor seperti keuntungan, penjualan, kesejahteraan karyawan, dan pasar saham. Pada situasi lain, satu pengambilan keputusan yang efektif juga dapat diartikan sebagai keputusan yang dapat meminimalkan kerugian, biaya, atau penggantian karyawan. Melengkapi unsur-unsur sebelumnya, Norman Maier (2000: 18) menegaskan bahwa keputusan yang efektif harus memenuhi dua unsur, yaitu: (a) kualitas sasaran keputusan tersebut (quality) dan (b) penerimaan dari individu-individu yang harus melaksanakannya (acceptability).

Berdasarkan uraian di atas, pengambilan keputusan dapat diartikan sebagai penetapan tujuan secara efektif yang mampu memecahkan masalah dengan risiko sekecil mungkin dengan indikator: (1) dapat mencapai sasaran yang dikehendaki; (2) dapat mengoptimalkan keuntungan; (3) dapat mengoptimalkan kesejahteraan karyawan; (4) dapat meminimalkan kerugian, biaya, atau penggantian karyawan; dan (5) penerimaan dari individu-individu pelaksananya. 


\section{Komitmen Organisasi}

Komitmen disadur dari bahasa Inggris commitment yang berarti janji atau tanggung jawab, didefinisikan sebagai tidak pernah memalingkan muka dari tujuan yang telah ditetapkan (Maxwell, 2000: 18). Kreitner dan Kinicki (2004: 698) menyatakannya sebagai sesuatu yang mencerminkan keluasan individu terlibat dalam tugas apa pun yang dikerjakannya. Melengkapi pendapat sebelumnya, Cooper dan Sawaf (2000: 273), mengutip pendapat Sternberg, mendefinisikan komitmen sebagai kemampuan menerjemahkan harapan atau teori ke dalam tindakan yang bermakna dan mengabstraksikan gagasan-gagasan ke dalam hal-hal yang praktis.

Di sisi lain, organisasi diartikan sebagai sekumpulan orang-orang yang bekerja-sama dalam suatu wahana yang terstruktur dan teratur untuk mencapai seperangkat tujuan (griffins, 1997: 4). Hersey dan Blanchard (2001: 9) berpendapat bahwa organisasi merupakan sistem sosial yang terdiri dari subsistem manusia, subsistem teknologi, subsistem, administratif, dan subsistem informasi. Melengkapi pendapat di atas, Robbins (1994: 4) mengemukakan bahwa suatu organisasi merupakan "kesatuan sosial yang dikordinasikan secara sadar dengan sebuah batasan yang relatif dapat diidentifikasi, yang bekerja atas dasar yang relatif terus menerus untuk mencapai suatu tujuan atau sekelompok tujuan".

Batasan yang terakhir ini mengisyaratkan bahwa organisasi memiliki beberapa kriteria, yaitu (1) kesatuan sosial, (2) dikordinasikan secara sadar, (3) memiliki batasan yang relatif dapat diidentifikasi, (4) bekerja atas dasar yang relatif terus menerus (5) mencapai suatu tujuan atau sekelompok tujuan. Kriteria pertama menginformasikan bahwa organisasi terdiri atas sekelompok orang yang saling berinteraksi satu sama lain. Pola interaksi tersebut tidak timbul begitu saja, melainkan telah ditata sedemikian rupa agar teratur dan seimbang.

Dalam konteks moral, komitmen dapat dibagi atas komitmen yang serius dan komitmen yang sepele (frivolous). Pembagian komitmen ke dalam dua kategori ini didasarkan atas tujuan seseorang menetapkan komitmen tersebut. Komitmen serius adalah komitmen yang dilakukan untuk sesuatu yang berhubungan dengan janji moral dan harga diri (self-respect), sedangkan komitmen yang dilakukan untuk sesuatu yang tidak berhubungan dengan masalah moral dan harga diri dapat dikelompokan sebagai komitmen yang bersifat frivolous. Sebagai contoh komitmen Gandhi untuk berpuasa dalam memperjuangkan ide-ide politiknya harus dianggap sebagai komitmen serius, sedangkan komitmen seseorang yang berpuasa hanya untuk mengurangi berat tubuhnya karena faktor obesitas dianggap sebagai suatu komitmen yang bersifat frivolous (Haflon,1989: 24 -25).

Sesuai dengan uraian di atas, maka dapat disimpulkan bahwa komitmen organisasi adalah keterikatan emosional diri individu dengan organisasi tempatnya bekerja yang dapat dilihat dari (1) keinginan untuk bertahan dalam organisasi; (2). berkorban demi organisasinya; (3). mematuhi aturan-aturan organisasi; (4) kebutuhan untuk memelihara tujuan organisasi, (5). berpartisipasi aktif dalam organisasi, (6). memajukan organisasi, (7) 
membalas jasa-jasa pimpinan; (8). membalas jasa-jasa organisasi, dan (9). memelihara hubungan dengan rekan kerja.

\section{MODEL HIPOTETIK} berikut.

Model hipotetik yang dibangun dalam penelitian ini dapat digambarkan sebagai

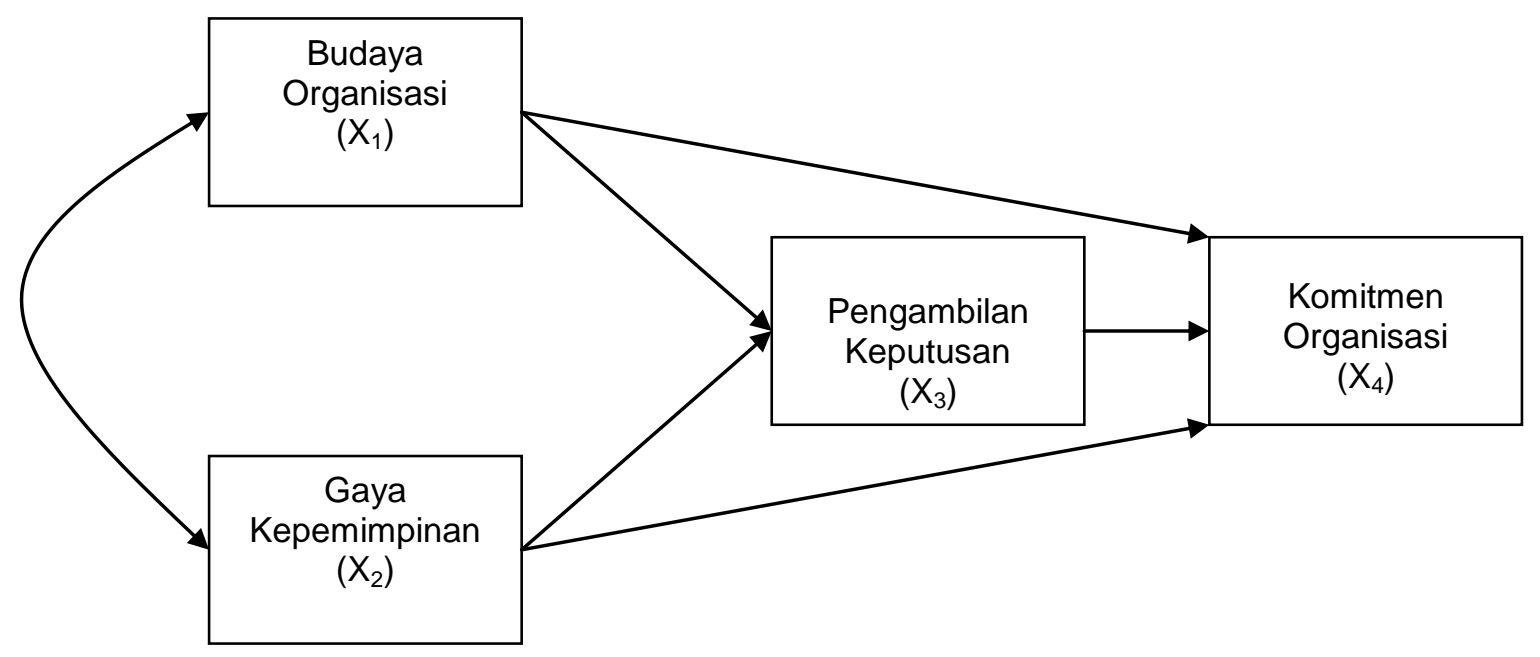

Gambar 2.4 : Model Hipotetik Penelitian

\section{METODOLOGI PENELITIAN}

Penelitian ini dilaksanakan di PT. Sucofindo. Populasinya adalah karyawan PT. Sucofindo yang berada di pusat, sedangkan populasi terjangkau adalah 700 orang. Sampel penelitian ditarik dengan menggunakan teknik penarikan sampel acak sederhana (simple random sampling). Ukuran sampel yang ditetapkan untuk penelitian ini adalah sebanyak 100 responden, yang didasarkan atas pendapat Sugiyono. Uji validitas reliabilitas butir instrumen ini dilakukan dengan $n=30$, pada $\alpha=0,05$ dan indeks penerimaan pada $r$ tabel $=$ 0,361 . Dengan demikian, jika $r_{\text {hit }}$ lebih besar dari $r_{\text {tabel }}=0,361$, maka butir dianggap valid,

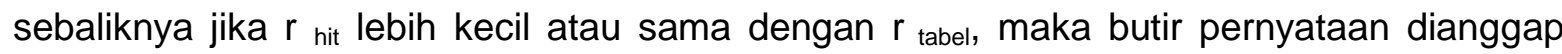
tidak valid dan dianggap gugur. Berdasarkan hasil perhitungan, terdapat dua butir pernyataan yang disusun tidak memenuhi persyaratan, yakni butir No 18 dengan $r_{\text {hitung }}=$ 0,287 dan No 32 dengan $r_{\text {hitung }}=0,272$. Dengan demikian, butir yang dinyatakan valid dan layak untuk digunakan sebagai instrumen penelitian berkurang menjadi 33 butir. Uji reliabilitas Instrumen penelitian yang terdiri atas: (a) komitmen organisasi yang hasil ujicoba memperlihatkan koefisien reliabilitas sebesar 0,903; (b) gaya kepemimpinan yang hasil ujicoba memperlihatkan koefisien reliabilitas sebesar $=0,913$; (c) budaya organisasi dengan koefisien reliabilitas sebesar $=0,943$, dan pengambilan keputusan dengan koefisien reliabilitas sebesar $=0,910$. Dengan demikian, semua instrumen penelitian yang digunakan untuk menjaring data penelitian valid dan realibel. Langkah selanjutnya dilakukan analisis :1) Kesesuain model hipotetis penelitian yang telah ditetapkan dengan 
menggunakan perhitungan indeks kesesuaian model (Goodness of Fit Indices/GFI) sebagai numerator dan indeks kesesuaian model yang disesuaikan (Adjusted Goodness of Fit Indices/AGFI) sebagai denumerator, jika harga GFI dan AGFI mendekati angka 1 maka dapat melakukan analisis jalur dan sebaliknya jika mendekati 0 maka mengganti model; 2) Signifikansi Koefisien korelasi karena analisis jalur hanya dapat dilakukan jika koefisien korelasinya adalah signifikan; 3) Analisis koefisien jalur untuk menentukan besaran pengaruh variabel berdasarkan jalurnya

\section{HASIL PENELITIAN}

\section{A. ANALISIS KESESUAIAN MODEL, KOEFISIEN KORELASI DAN KOEFISIEN JALUR}

Hasil analisis korelasi untuk model hipotetis penelitian yang ditampilkan pada Gambar 2.4 di atas menegaskan bahwa terdapat enam pasang harga korelasi, yakni: $r_{21}$, $r_{31}, r_{41}, r_{32}, r_{42}$, dan $r_{43}$. Meskipun demikian, tidak semua harga korelasi pasangan variabel ini akan digunakan melainkan harus disesuaikan dengan model hipotetis penelitian. Dengan demikian, sebelum menentukan jalur yang akan diuji, terlebih dahulu dirujuk kembali pada model hipotetis yang telah ditetapkan. Jalur yang akan diuji dalam model hipotetis penelitian dapat digambarkan kembali seperti terlihat pada Gambar berikut.

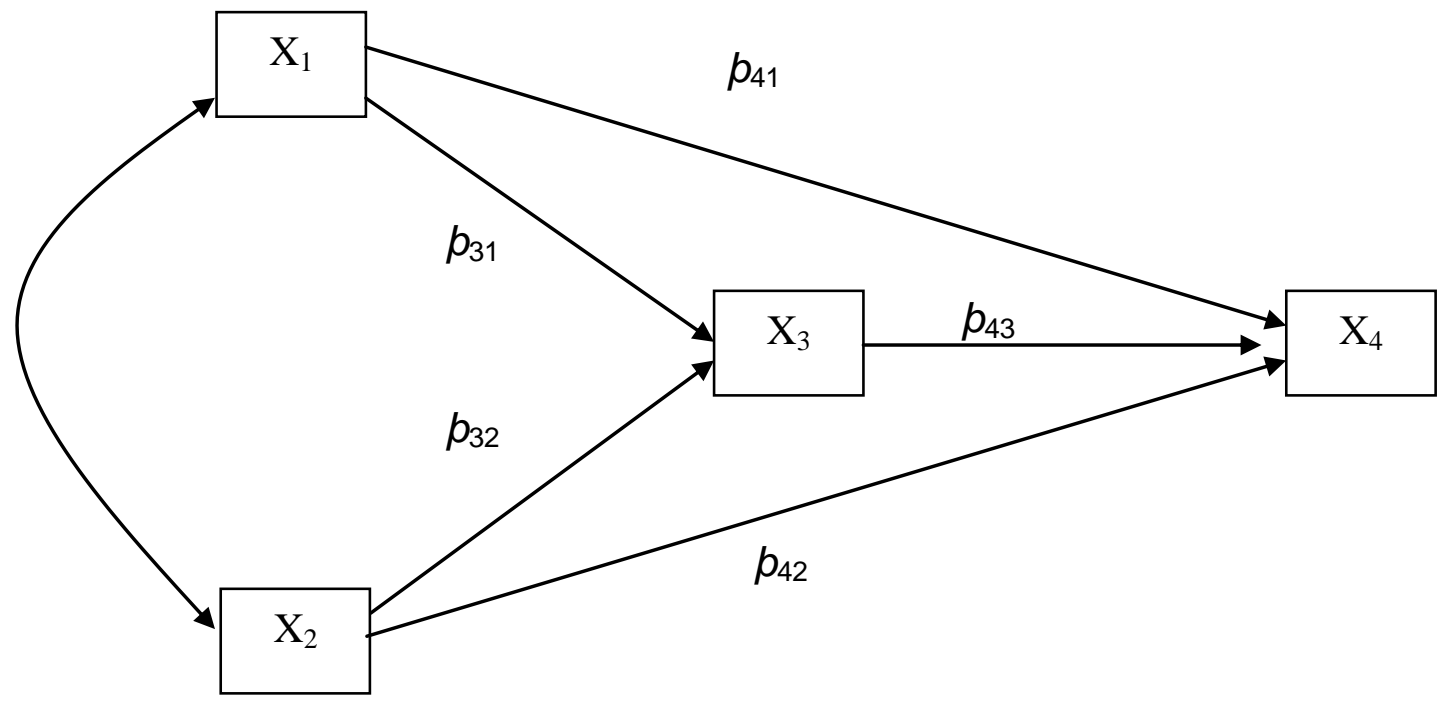

Gambar 4.1 : Model Jalur

Dari gambar model jalur ini, dapat diketahui bahwa meskipun harga korelasi antarvariabel terdiri atas enam pasangan, namun dalam model hipotetisnya hanya memiliki lima jalur yaitu $p_{31}, p_{41}, p_{32}, p_{42}$ dan $p_{43}$. Berikutnya adalah menguji kesesuaian model teoretik yang dikonstruksikan tersebut secara empirik. Langkah yang harus ditempuh untuk uji kesesuaian model ini adalah dengan menggunakan perhitungan indeks kesesuaian model (Goodness of Fit Indices/GFI) sebagai numerator dan indeks kesesuaian model yang disesuaikan (Adjusted Goodness of Fit Indices/AGFI) sebagai denumerator. Kriteria pengujiannya adalah 
(a) jika harga GFI dan AGFI mendekati angka 1, berarti model yang dikonstruksikan telah sesuai dan selanjutnya dapat melakukan analisis jalur;

(b) sebaliknya, jika harga GFI dan AGFI mendekati angka 0, berarti model yang dikonstruksikan tidak sesuai dan selanjutnya lebih baik mengganti modelnya.

Berdasarkan hasil analisis data, diperoleh harga $\mathrm{GFI}=0,97$ dan $\mathrm{AGFI}=0,92$ yang berarti model yang telah dikonstruksikan secara teoretik dapat diterima secara empirik. Hal ini mengisyaratkan bahwa proses pengujian jalur dapat dilanjutkan.

Langkah berikutnya adalah menghitung harga signifikansi koefisien korelasi yang terdapat pada model. Hal ini mutlak dilakukan karena pengujian jalur hanya dapat dilakukan jika koefisien korelasinya adalah signifikan. Berdasarkan hasil analisis data, harga koefisien korelasi untuk masing-masing jalur yang akan diuji dapat dilihat pada Tabel berikut.

Tabel 4.1. : Signifikansi Koefisien Korelasi

\begin{tabular}{|c|c|c|c|c|c|}
\hline \multirow[b]{2}{*}{ Korelasi } & \multirow{2}{*}{$\begin{array}{l}\text { Koefisien } \\
\text { Korelasi }\end{array}$} & \multirow[b]{2}{*}{$t_{\text {hitung }}$} & \multicolumn{2}{|c|}{$t_{\text {tabel }}$} & \multirow[b]{2}{*}{ Keterangan } \\
\hline & & & $\alpha=0,05$ & $\alpha=0,01$ & \\
\hline$r_{31}$ & 0,56 & $7,42^{\star *}$ & 1,96 & 2,56 & Sangat Signifikan \\
\hline$r_{41}$ & 0,52 & $5,99^{\star *}$ & 1,96 & 2,56 & Sangat signifikan \\
\hline$r_{32}$ & 0,39 & $4,20^{\star *}$ & 1,96 & 2,56 & Sangat signifikan \\
\hline$r_{42}$ & 0,26 & $2,68^{* \star}$ & 1,96 & 2,56 & Sangat signifikan \\
\hline$r_{43}$ & 0,52 & $6,03^{\star *}$ & 1,96 & 2,56 & Sangat signifikan \\
\hline
\end{tabular}

${ }^{* *}=$ Signifikan pada $\alpha=0,01$

Berdasarkan hasil analisis di atas, kelima koefisien korelasi dalam model hipotetis telah teruji berkorelasi secara signifikan. Dengan demikian, model hipotesis penelitian dapat diklasifikasikan sebagai model yang baik dan benar, sehingga model tidak mengalami perubahan lagi sebagaimana yang telah disesuaikan. Model akhir hasil pengujian tersebut dapat dijadikan sebagai model strukural hubungan antarvariabel. Untuk lebih jelasnya, struktur model dan jalur yang akan diuji dapat digambarkan sebagai berikut.

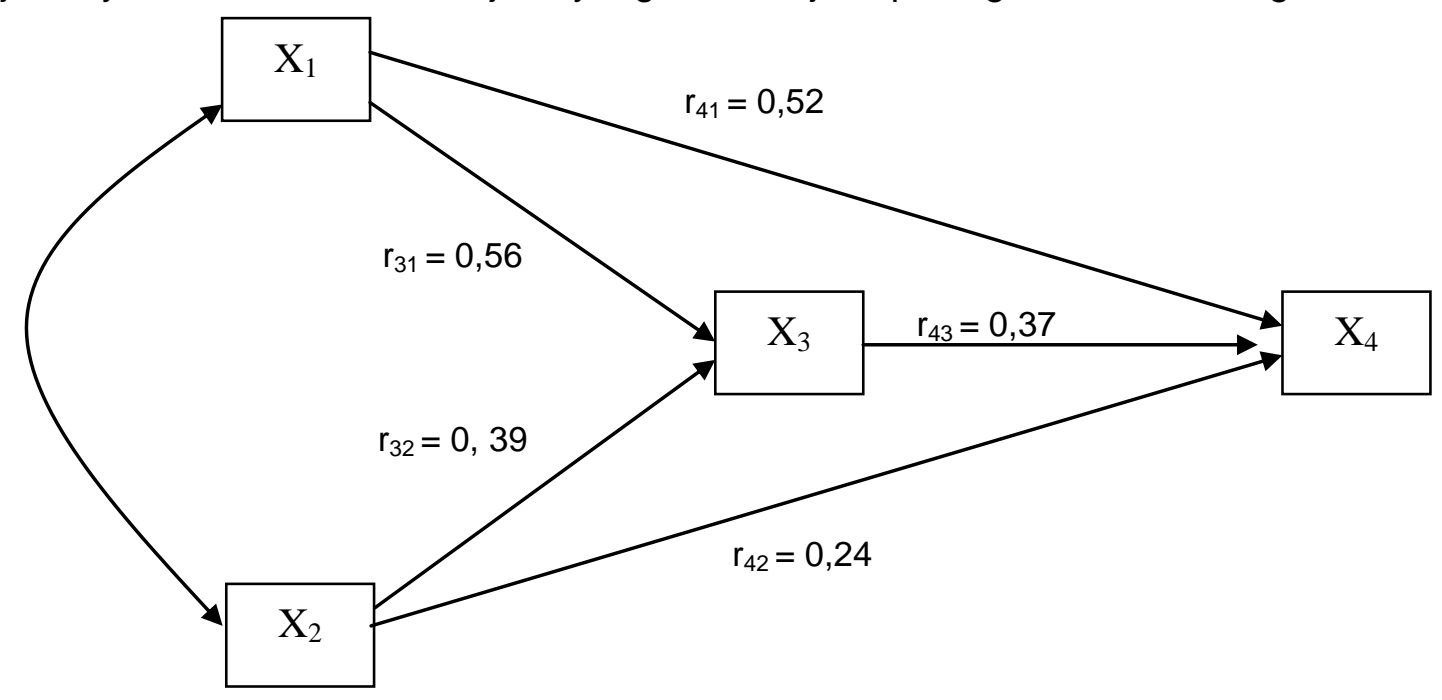

Gambar 4.2 : Model Hubungan Struktural Antar Variabel 
Berdasarkan Gambar di atas, terlihat bahwa pasangan variabel yang memiliki hubungan yang relatif paling besar yaitu pasangan variabel budaya organisasi $\left(\mathrm{X}_{1}\right)$ dengan variabel pengambilan keputusan $\left(X_{3}\right)$ dengan nilai koefisien korelasi $r_{31}=0,56$. Ini menggambarkan bahwa variabel budaya organisasi dengan pengambilan keputusan berhubungan cukup kuat. Berikutnya pasangan variabel budaya organisasi $\left(X_{1}\right)$ dengan komitmen organisasi $\left(X_{4}\right)$ dengan koefisien korelasi $r_{41}$ sebesar 0,52 . Posisi ketiga ditempati oleh pasangan variabel pengambilan keputusan $\left(X_{3}\right)$ dengan komitmen organisasi $\left(X_{4}\right)$ dengan koefisien korelasi $r_{41}=0,52$. Posisi berikutnya adalah pasangan variabel gaya kepemimpinan $\left(X_{2}\right)$ dengan pengambilan keputusan $\left(X_{3}\right)$ dengan koefisian korelasi $r_{41}=$ 0,39 dan terakhir adalah pasangan variabel gaya kepemimpinan $\left(\mathrm{X}_{2}\right)$ dengan komitmen organisasi (X4) yang memiliki koefisien korelasi sebesar 0,26.

Berikutnya adalah mencari harga koefisien jalur masing-masing struktur pasangan variabel. Hal ini mutlak dilakukan untuk menentukan besaran pengaruh variabel berdasarkan jalurnya. Berdasarkan hasil analisis data, harga koefisien jalur untuk masingmasing struktur dapat dilihat pada Tabel berikut.

Tabel 4.2. : Koefisien Jalur dan Signifikansinya

\begin{tabular}{|c|c|c|c|c|c|}
\hline \multirow{2}{*}{ Jalur } & \multirow{2}{*}{$\begin{array}{c}\text { Koefisien } \\
\text { Jalur }\end{array}$} & \multirow{2}{*}{$\mathbf{t}_{\text {hitung }}$} & \multicolumn{2}{|c|}{$\mathbf{t}_{\text {tabel }}$} & \multirow{2}{*}{ Keterangan } \\
\cline { 4 - 5 } & & & $\alpha=\mathbf{0 , 0 5}$ & $\boldsymbol{\alpha}=\mathbf{a , 0 1}$ & \\
\hline$P_{31}$ & 0,45 & $4,01^{* *}$ & 1,96 & 2,56 & Sangat Signifikan \\
\hline$P_{41}$ & 0,41 & $3,76^{* *}$ & 1,96 & 2,56 & Sangat signifikan \\
\hline$P_{42}$ & 0,24 & $2,14^{* *}$ & 1,96 & 2,56 & Sangat signifikan \\
\hline$P_{32}$ & 0,41 & $3,78^{\star *}$ & 1,96 & 2,56 & Sangat signifikan \\
\hline$P_{43}$ & 0,37 & $3,11^{* *}$ & 1,96 & 2,56 & Sangat signifikan \\
\hline
\end{tabular}

Tabel 4.2 di atas menginformasikan bahwa pengaruh yang paling besar dalam model struktur hipotetis ini adalah pasangan variabel budaya organisasi $\left(X_{1}\right)$ dengan variabel pengambilan keputusan $\left(X_{3}\right)$ dengan nilai koefisien jalur $p_{31}=0,45$. Berikutnya pasangan variabel budaya organisasi $\left(X_{1}\right)$ dengan komitmen organisasi $\left(X_{4}\right)$ dengan koefisien jalur $p_{41}$ $=0,41$. Posisi ke tiga ditempati oleh pasangan variabel gaya kepemimpinan $\left(X_{2}\right)$ dengan pengambilan keputusan $\left(\mathrm{X}_{3}\right)$ dengan koefisien jalur $p_{32}=0,41$. Posisi berikutnya ditempati oleh pasangan pengambilan keputusan $\left(X_{3}\right)$ dengan komitmen organisasi $\left(X_{4}\right)$ dengan koefisien jalur $p_{43}=0,37$. Posisi terakhir diduduki oleh pasangan variabel gaya kepemimpinan $\left(\mathrm{X}_{2}\right)$ dengan komitmen organisasi dengan koefisian jalur $p_{42}=0,24$. Berdasarkan harga-harga ini, maka sementara dapat disimpulkan bahwa pasangan variabel yang harga koefisien jalurnya paling tinggi adalah pasangan variabel budaya organisasi dengan pengambilan keputusan.

\section{B. PENGUJIAN HIPOTESIS}

\section{Pengaruh Langsung Budaya Organisasi $\left(X_{1}\right)$ terhadap Pengambilan keputusan}

$\left(\mathrm{X}_{3}\right)$

Hipotesis yang diuji adalah: 
$\mathrm{H}_{0}: p_{31}=0$

$\mathrm{H}_{1}: p_{31}>0$

Hasil analisis data menginformasikan bahwa harga koefisien jalur $\left(p_{31}\right)=0,45$. Pada sisi lain, diperoleh juga harga $t_{\text {hitung }}=4,01$, sedangkan harga $t_{\text {tabel }}(\alpha=0,01)=2,56$. Fakta ini mengungkapkan bahwa $t_{\text {hitung }}=4,01>\mathrm{t}_{\text {tabel }}=2,56$ yang berarti $\mathrm{H}_{0}$ ditolak dan $\mathrm{H}_{1}$ diterima. Artinya, koefisien jalur ini sangat signifikan. Temuan ini dapat diinterpretasikan bahwa budaya organisasi $\left(X_{1}\right)$ berpengaruh langsung terhadap pengambilan keputusan $\left(X_{3}\right)$.

2. Pengaruh Langsung Budaya Organisasi $\left(X_{1}\right)$ terhadap Komitmen Organisasi $\left(X_{4}\right)$ Hipotesis yang diuji adalah:

$\mathrm{H}_{0}: p_{41}=0$

$\mathrm{H}_{1}: p_{41}>0$

Hasil analisis data menginformasikan bahwa harga koefisien jalur $\left(\rho_{41}\right)=0,411$ dengan harga $t_{\text {hitung }}=3,78$. Pada sisi lain, harga $t_{\text {tabel }} \alpha(a l p h a=0,01)=2,56$. Hal ini berarti bahwa $\mathrm{t}_{\text {hitung }}=3,78>\mathrm{t}_{\text {tabel }}=2,56$ yang berarti $\mathrm{H}_{0}$ ditolak dan $\mathrm{H}_{1}$ diterima. Artinya, koefisien jalur ini sangat signifikan. Dengan demikian, dapat diinterpretasikan bahwa budaya organisasi berpengaruh langsung terhadap komitmen organisasi.

3. Pengaruh Langsung Gaya kepemimpinan $\left(X_{2}\right)$ terhadap Pengambilan Keputusan $\left(\mathbf{X}_{3}\right)$

Hipotesis yang diuji adalah:

$\mathrm{H}_{0}: p_{32}=0$

$\mathrm{H}_{1}: p_{32}>0$

Berdasarkan hasil perhitungan data, diperoleh informasi bahwa harga koefisien jalur $\left(p_{32}\right)=$ 0,41 . Harga $t_{\text {hitung }}=4,76$ dan harga $t_{\text {tabel }}$ untuk $\alpha$ (alpha) sebesar $0,01=2,56$. Fakta ini mengungkapkan bahwa $\mathrm{t}_{\text {hitung }}=4,76>\mathrm{t}_{\text {tabel }}=2,56$ yang berarti $\mathrm{H}_{0}$ ditolak dan $\mathrm{H}_{1}$ diterima. Artinya, koefisien jalur ini sangat signifikan. Temun Ini menegaskan bahwa gaya kepemimpinan $\left(\mathrm{X}_{2}\right)$ berpengaruh langsung terhadap pengambilan keputusan $\left(\mathrm{X}_{3}\right)$.

\section{Pengaruh Langsung Gaya kepemimpinan $\left(X_{2}\right)$ terhadap Komitmen Organisasi $\left(X_{4}\right)$} Hipotesis yang diuji adalah:

$\mathrm{H}_{0}: p_{42}=0$

$\mathrm{H}_{1}: p_{42}>0$

Hasil analisis data menginformasikan bahwa harga koefisien jalur $\left(p_{42}\right)=0,24$. Harga $t_{\text {hitung }}=$ 2,14 lebih. Angka ini lebih kecil jika dibandingkan dengn $t$ tabel untuk $(\alpha=0,01)=2,56$, tetapi lebih besar untuk $(\alpha=0,05)=1,96$. Fakta ini mengungkapkan bahwa $t_{\text {hitung }}=2,14>t$ tabel $=1,96$ yang berarti $\mathrm{H}_{0}$ ditolak dan $\mathrm{H}_{1}$ diterima. Artinya, koefisien jalur ini sangat signifikan. Temuan ini mengandung arti bahwa gaya kepemimpinan $\left(\mathrm{X}_{2}\right)$ berpengaruh langsung terhadap komitmen organisasi $\left(\mathrm{X}_{4}\right)$.

\section{Pengaruh Langsung Pengambilan keputusan $\left(X_{3}\right)$ terhadap Komitmen Organisasi} $\left(\mathrm{X}_{4}\right)$

Hipotesis yang diuji adalah:

$\mathrm{H}_{0}: p_{43}=0$

$\mathrm{H}_{1}: p_{43}>0$ 
Hasil analisis data menginformasikan bahwa harga koefisien jalur $\left(p_{43}\right)=0,37$ dengan harga $t_{\text {hitung }}=3,11$. Pada sisi lain, harga $t_{\text {tabel }}$ untuk $\alpha$ (alpha) sebesar $0,01=2,56$. Fakta ini menegaskan bahwa $t_{\text {hitung }}=3,11>\mathrm{t}_{\text {tabel }}=2,56$ yang berarti $\mathrm{H}_{0}$ ditolak dan $\mathrm{H}_{1}$ diterima. Artinya, koefisien jalur ini sangat signifikan.Temuan ini menegaskan bahwa pengambilan keputusan $\left(\mathrm{X}_{3}\right)$ berpengaruh langsung terhadap komitmen organisasi $\left(\mathrm{X}_{4}\right)$.

\section{Pengaruh Tidak Langsung Budaya Organisasi $\left(X_{1}\right)$ terhadap Komitmen Organisasi}

\section{$\left(X_{4}\right)$ melalui Pengambilan keputusan $\left(X_{3}\right)$}

Merujuk pada temuan penelitian di atas, maka dapat dicari pengaruh tidak langsung budaya organisasi terhadap komitmen organisasi melalui pengambilan keputusan dengan perhitungan $p_{41 \times} p_{43}$. Hasil perhitungan menginformasikan bahwa harga koefisien jalur $\left(p_{41}\right)$ $=0,45$ sedangkan harga koefisien jalur $\left(p_{43}\right)=0,37$. Dengan demikian, pengaruh tidak langsung budaya organisasi terhadap komitmen organisasi melalui pengambilan keputusan adalah $0,45 \times 0,37=0,17$.

\section{7 . Pengaruh Tidak Langsung Gaya kepemimpinan $\left(X_{2}\right)$ terhadap Komitmen Organisasi $\left(\mathrm{X}_{4}\right)$ melalui Pengambilan keputusan $\left(\mathrm{X}_{3}\right)$}

Dengan mengikuti prosedur yang telah ditempuh sebelumnya, pengaruh tidak langsung gaya kepemimpinan $\left(X_{2}\right)$ terhadap komitmen organisasi $\left(X_{4}\right)$ melalui pengambilan keputusan $\left(\mathrm{X}_{3}\right)$ dapat dicari melalui perhitungan $p_{42} \times p_{43}=0,24 \times 0,37=0,09$. Dengan demikian, pengaruh tidak langsung variabel gaya kepemimpinan terhadap komitmen organisasi melalui pengambilan keputusan adalah $=0,09$.

Rangkuman analisis ini dapat dilihat pada tabel berikut.

Tabel 4.3. : Rangkuman Analisis

\begin{tabular}{|c|c|c|c|c|}
\hline No. & Hipotesis & Uji Statistik & Keputusan $\mathrm{H}_{\mathrm{o}}$ & Kesimpulan \\
\hline 1. & $\begin{array}{l}\text { Budaya organisasi berpengaruh } \\
\text { langsung terhadap pengambilan } \\
\text { keputusan }\end{array}$ & $\begin{array}{l}\mathrm{H}_{0}: p_{31}=0 \\
\mathrm{H}_{1}: p_{31}>0\end{array}$ & Ditolak & $\begin{array}{lr}\text { Memiliki } \quad \text { pengaruh } \\
\text { langsung secara } \\
\text { sangat signifikan }\end{array}$ \\
\hline 2. & $\begin{array}{l}\text { Budaya organisasi berpengaruh } \\
\text { langsung terhadap komitmen } \\
\text { organisasi }\end{array}$ & $\begin{array}{l}\mathrm{H}_{0}: p_{41}=0 \\
\mathrm{H}_{1}: p_{41}>0\end{array}$ & Ditolak & $\begin{array}{lr}\text { Memiliki } & \text { pengaruh } \\
\text { langsung secara } & \text { sangat signifikan }\end{array}$ \\
\hline 3. & $\begin{array}{l}\text { Gaya kepemimpinan berpenga- } \\
\text { ruh langsung terhadap pengam- } \\
\text { bilan keputusan }\end{array}$ & $\begin{array}{l}\mathrm{H}_{0}: p_{32}=0 \\
\mathrm{H}_{1}: p_{32}>0\end{array}$ & Ditolak & $\begin{array}{lr}\text { Memiliki } & \text { pengaruh } \\
\text { langsung secara } \\
\text { sangat signifikan }\end{array}$ \\
\hline 4. & $\begin{array}{l}\text { Gaya kepemimpinan berpenga- } \\
\text { ruh langsung terhadap komit- } \\
\text { men organisasi }\end{array}$ & $\begin{array}{l}\mathrm{H}_{0}: p_{42}=0 \\
\mathrm{H}_{1}: p_{42}>0\end{array}$ & Ditolak & $\begin{array}{lr}\text { Memiliki } & \text { pengaruh } \\
\text { langsung } & \text { secara } \\
\text { signifikan } & \end{array}$ \\
\hline 5. & $\begin{array}{l}\text { Pengambilan keputusan } \\
\text { berpengaruh langsung terhadap } \\
\text { komitmen organisasi }\end{array}$ & $\begin{array}{l}\mathrm{H}_{0}: p_{43}=0 \\
\mathrm{H}_{1}: p_{43}>0\end{array}$ & Ditolak & $\begin{array}{l}\text { Memiliki pengaruh } \\
\text { langsung secara } \\
\text { sangat signifikan }\end{array}$ \\
\hline 6 & $\begin{array}{l}\text { Budaya organisasi berpengaruh } \\
\text { langsung terhadap komitmen } \\
\text { organisasi melalui pengambilan } \\
\text { keputusan }\end{array}$ & $\begin{array}{l}\mathrm{H}_{0}: p_{31} \times p_{43}=0 \\
\mathrm{H}_{1}: p_{31} \times p_{43}>0\end{array}$ & Ditolak & $\begin{array}{l}\text { Memiliki pengaruh tidak } \\
\text { langsung }\end{array}$ \\
\hline 7 & $\begin{array}{l}\text { Gaya kepemimpinan berpenga- } \\
\text { ruh langsung terhadap omitmen } \\
\text { organisasi melalui pengambilan } \\
\text { keputusan }\end{array}$ & $\begin{array}{l}\mathrm{H}_{0}: p_{32} \times p_{43}=0 \\
\mathrm{H}_{1}: p_{32} \times p_{43}>0\end{array}$ & Ditolak & $\begin{array}{l}\text { Memiliki pengaruh tidak } \\
\text { langsung }\end{array}$ \\
\hline
\end{tabular}




\section{KESIMPULAN DAN SARAN}

\section{A. KESIMPULAN}

Dari hasil analisis dan pembahasan yang telah dijelaskan pada Bab IV, maka temuan penelitian ini adalah:

1. Budaya organisasi berpengaruh langsung terhadap pengambilan keputusan. Hasil inl memberikan makna bahwa efektifitas dalam pengambilan keputusan, salah satunya ditentukan oleh budaya organisasi.

2. Budaya organisasi berpengaruh langsung terhadap komitmen organisasi. Hasil ini memberikan makna bahwa tinggi rendahnya komitmen organisasi, salah satunya ditentukan oleh budaya organisasi.

3. Gaya kepemimpinan berpenqaruh langsung terhadap pengambilan keputusan. Temuan ini menunjukkan bahwa efektifitas dalam pengambilan keputusam salah satunya dipengaruhi oleh gaya kepemimpinan.

4. Gaya kepemimpinan berpengaruh langsung terhadap komitmen organisasi. Temuan ini menunjukkan bahwa tinggi rendahnya komitmen organisasi salah-satunya dipengaruhi oleh gaya kepemimpinan.

5. Pengambilan keputusan berpengaruh langsung terhadap komitmen organisasi. Hal ini berarti bahwa tinggi rendahnya komitmen organisasi salah satunya ditentukan oleh pengambilan keputusan.

6. Budaya organisasi berpengaruh tidak langsung terhadap komitmen organisasi dengan diperantarai pengambilan keputusan. Hasil ini menunjukkan bahwa kondisi budaya organisasi yang baik akan mempengaruhi dalam pengambilan keputusan, dan selanjutnya berpengaruh terhadap komitmen organisasi.

7. Gaya kepemimpinan berpengaruh tidak langsung terhadap komitmen organisasi dengan diperantarai pengambilan keputusan. Hasil ini memberikan pengertian bahwa gaya kepemimpinan yang dipersepsi baik akan berdampak terhadap peningkatan efektivitas pengambilan keputusan, yang selanjutnya berpengaruh terhadap meningkatnya komitmen organisasi.

Berdasarkan temuan-temuan di atas, maka dapat disimpulkan bahwa variasi yang terjadi pada komitmen organisasi secara langsung dipengaruhi oleh budaya organisasi, gaya kepemimpinan dan pengambilan keputusan dan secara tidak langsung dipengaruhi oleh budaya organisasi dan gaya kepemimpinan melalui pengambilan keputusan. Oleh karena itu, untuk meminimalkan variasi yang terjadi pada komitmen organisasi, faktor budaya organisasi, gaya kepemimpinan dan pengambilan keputusan perlu dipertimbangkan.

\section{B. SARAN}

1. Manajemen PT Sucofindo (Persero) perlu melakukan evaluasi terhadap pelaksanaan nilai-nilai budaya perusahaan. Perusahaan seharusnya mengembangkan alat ukur yang yang dapat digunakan secara periodik guna mengevaluasi budaya organisasi pada perusahaan tersebut. Hasil evaluasi tersebut digunakan sebagai masukan untuk 
memperkuat budaya organisasi di masa yang akan datang agar proses pengambilan keputusan dapat berjalan secara lebih efektif yang pada akhirnya nanti akan dapat meningkatkan komitmen organisasi.

2. Selain itu, perusahaan juga perlu merumuskan gaya kepemimpinan seperti apa yang dibutuhkan para anggota organisasi agar mereka dapat membuat keputusan yang lebih baik, tidak hanya untuk dirinya, tetapi juga untuk kemajuan perusahaan.

3. Unsur pimpinan pada PT Sucofindo (Persero) perlu terus menerus meningkatkan kesadaran diri agar dapat mengetahui kelemahan-kelemahan kepemimpinannya sendiri. Kesadaran diri menjadi dasar yang kuat agar pemimpin bersedia mengubah gaya yang menyebabkan kepemimpinannya menjadi tidak efektif. Langkah ini juga akan mendorong seorang pemimpin untuk terus berbenah diri dan berhati-hati dalam mengambil sikap dan tindakan. Untuk dapat memiliki kesadaran diri yang tinggi, maka diperlukan pelatihan-pelatihan dan pengalaman-pengalaman yang berjenjang agar pada saat mencapai puncak kepemimpinannya tidak menimbulkan kontroversi yang dapat menurunkan moral anggota organisasi.

4. Manajemen PT Sucofindo (Persero) perlu membangun hubungan sosial yang lebih harmonis, mengembangkan sistem kompensasi yang fair dan memberikan umpan balik positif terhadap karyawan dalam rangka meningkatkan komitmen organisasi ini.

\section{DAFTAR PUSTAKA}

Bender, Peter Urs. Leadership From Within. Canada: Stoddart Publishing, 1997

Certo, David. Organizational Behavior. McGraw-Hill Book, 2003

Clemen, William B. Decission Making. New Jersey: Prentice Hall, 1996

Colquitt, Jasoon A., Jeffery A. Lepine \& Michael J. Wesson, Organizational Behavior . Boston: McGraw Hill, 2009

Cooper, Robert K. \& Ayman Sawaf, Executive EQ, terjemahan Alex Tri Kantjono Widodo. Jakarta: Gramedia, 2000

Draft, Richard L. The Leadership Experiences. South Western: Thomson, 2005

Deal, Terrence E. "Developing A Quality Culture" dalam Ralph H. Kilmann, Ines Kilmann \& Associates (eds.), Making Organizations Competitive. San Francisco: Josey-Bass Publishers, 1991

Flaney, Thomas P., David A. Hofrichter, dan Paul E. Platten, People, Performance, and Pay. New York: Free Press, 1996

George, Jennifer M. \& Gareth R. Jones. Organizational Behavior. New Jersey: Prentice-Hall, 2002 Griffin, Ricky W. Management. New Delhi: A.I.T.B.S. Publishers \& Distributors, 1997

Haflon, Marks S. Integrity: A Philosophical Inquiry. Philadelphia: Temple University Press, 1989 Hersey, Paul \& Kenneth H. Blanchard, Organization Human Behavior. New Jersey: Prentice Hall, 2001

Hofstede, Geert. Cultures and Organizations. London: McGraw-Hill International, 1994

Hunsaker, Phillip L. Training in Management Skills. New Jersey: Prentice Hall, 2001

Inamori, Kazuo. For People and For Profit. Tokyo: Kodansha International Ltd., 1997 
Kelley, Robert E. "Combining Followership and Leadership into Partnership" dalam Ralp H. Kilmann Ines Kilmann and Associates (eds.). Making Organizations Competitive. .San Fransisco: Jossey-Bass Publishers, 1991

Kotter, John P. dan James L. Hesket, Corporate Culture and Performance, terjemahan Benyamin Molan. Jakarta: PT. Prenhallindo, 1997

Kreitner, Robert dan Angelo Kinicki, Organizational Behavior. Boston: Richard D. IRWIN, Inc., 2004

Luthans, Fred. Organizational Behavior . New York: McGraw-Hill, Inc., 2008

Maxwell, John C. Qualities of A Leader. Mumbai: Magna Publishing Co. Ltd., 2000

McShane, Steven L. \& Mary Ann Von Glinow, Organizational Behavior. Boston: McGraw-Hill, 2005

Meir, Norman. Decision Making Process. Singapore: Magna Publishing Co. Ltd., 2000

Mondy, R. Wayne et al, Human Resource Management. New Jersey: Prentice-Hall, Inc., 1996

Newstrom, John W. \& Keith Davis. Organizational Behavior: Human Behavior at Work. New Delhi, Tata McGraw-Hill Publishing Co. Ltd., 2001

Robbins, Stephen P. Teori Organisasi: Struktur, Desain dan Aplikasi, terjemahan. Jusuf Udaya .Jakarta: Arcan, 1994

\& William A. Judge, Organizational Behavior. New Jersey: Prentice Hall, 2007

\& David Coulter, Organizational Behavior. New Jersey: Prentice Hall, 1999

Simon, Herbert A. Administrative Behavior. New York: The Free Press, 1997

Turban, David, William B. Aronson, dan David Liang, Organizational Behavior. New Jersey: Prentice Hall, 2005

Yukl, Gary, Leadership In Organizations. New Jersey: Pearson Prentice Hall, 2010

Wagner, John A. III dan John R. Hollenbeck, Management of Organizational Behavior. New Jersey: Prentice- Hall, Inc., 1992 